\title{
Interleukin 3 Stimulates Proliferation and Triggers Endothelial-Leukocyte Adhesion Molecule 1 Gene Activation of Human Endothelial Cells
}

\author{
Maria Felice Brizzi, * Giovanni Garbarino, ${ }^{*}$ Pier Riccardo Rossi, * Giovanni Luca Pagliardi, ${ }^{*}$ Carlo Arduino, \\ Gian Carlo Avanzi, * and Luigi Pegoraro* \\ ${ }^{*}$ Dipartimento di Scienze Biomediche e Oncologia Umana ${ }^{\ddagger}{ }^{\ddagger}$ Istituto di Medicina Interna, and ${ }^{\S}$ Dipartimento di Genetica, \\ Biologia e Chimica Medica, Università di Torino, 10126 Torino, Italy
}

\begin{abstract}
Proliferation and functional activation of endothelial cells within a tissue site of inflammation are regulated by humoral factors released by cells, such as $\mathbf{T}$ lymphocytes and monocytes, infiltrating the perivascular space. In the present study we investigated the effects of interleukin 3 (IL-3), an activated T lymphocyte-derived cytokine, on cultured human umbilical vein endothelial cells (HUVEC). Proliferative activity, evaluated both by estimation of the fraction of cells in the $S$ phase and by direct cell count demonstrated that IL-3, at the dose of $25 \mathrm{ng} / \mathrm{ml}$, enhances more than threefold both DNA synthesis and cell proliferation above baseline control conditions. Binding studies with radioiodinated ligand demonstrated that HUVEC constitutively express a small number of IL-3 binding sites ( 99 binding sites per cell, with an apparent $K_{d}$ of 149 pM). Accordingly, molecular analysis showed the presence of transcripts for both $\alpha$ and $\beta$ subunits of the IL-3 receptor. Functional activation of endothelial cells was evaluated by the expression of the endothelial-leukocyte adhesion molecule 1 (ELAM-1 ) transcript and by leukocyte adhesion. The ELAM1 gene transcript was clearly detectable $4 \mathrm{~h}$ after IL-3 addition and started to decrease after $12 \mathrm{~h}$. Moreover, IL-3-induced ELAM-1 transcription was followed by enhanced adhesion of neutrophils and $\mathrm{CD4}^{+} \mathrm{T}$ cells to HUVEC. The findings that IL-3 can stimulate both proliferation and functional activation of endothelial cells suggest that this cytokine can be involved in sustaining the process of chronic inflammation. (J. Clin. Invest. 1993. 91:2887-2892.) Key words: endothelial cells • endothelial-leukocyte adhesion molecule 1 - inflammation • interleukin $3 \cdot$ proliferation
\end{abstract}

\section{Introduction}

IL-3 is a glycoprotein that not only promotes the survival, proliferation, and differentiation of hemopoietic progenitor cells of several lineages including granulocytes, erythrocytes, monocytes, megakaryocytes, and lymphocytes but also modulates

Address reprint requests to Dr. Luigi Pegoraro, Dipartimento di Scienze Biomediche e Oncologia Umana, Sezione Clinica, Università di Torino, via Genova 3, 10126 Torino, Italy.

Received for publication 5 June 1992 and in revised form 12 February 1993

J. Clin. Invest.

(c) The American Society for Clinical Investigation, Inc.

$0021-9738 / 93 / 06 / 2887 / 06 \$ 2.00$

Volume 91, May 1993, 2887-2892 the activity of mature cells (1). These effects are mediated by specific high- or low-affinity membrane receptors (2-4). The ability of the IL-3 receptor to bind its ligand with different degrees of affinity depends on the presence of two transmembrane proteins, the $\alpha$ and $\beta$ subunits $(5,6)$. Recent studies have demonstrated that the $\alpha$ subunit binds specifically IL-3 (6), while the $\beta$ subunit, which confers high affinity to the receptor, is shared with GM-CSF and IL-5 receptors (7). IL-3 is produced predominantly by subfractions of $\mathrm{CD} 4^{+}$and $\mathrm{CD} 8^{+} \mathrm{T}$ lymphocytes undergoing antigenic or mitogenic stimulation $(1,8)$ and by activated mast cells $(9,10)$. These cells are essential mediators of normal tissue inflammatory and allergic reactions and of tissue damage in many autoimmune diseases. They play an important role not only as effector cells, but also as regulatory cells releasing a vast array of lymphokines (11). At the site of inflammation, a massive infiltration of activated $\mathrm{T}$ lymphocytes expressing the transcript of several lymphokines including IL-3 has been reported (12). However, no direct evidence has been so far provided that IL-3 is locally released in this context, nor has a possible role of IL-3 in the inflammatory process ever been taken into consideration.

Within tissue sites of inflammation, activated $\mathrm{T}$ lymphocytes are strictly associated with endothelial cells. These, in turn, play a central role in the inflammatory process not only as a target for injury but also, under the effect of leukocytederived cytokines, perform a variety of metabolic functions that influence the activity of smooth muscle, platelets, and polymorphonuclear leukocytes (PMN) (13). Moreover, the endothelium controls the traffic of molecules and cells between the blood and sites of immunological challenge. The promotion of leukocyte adhesion to the vascular endothelium is a crucial and early step in mounting an effective inflammatory or immune response. Endothelial cells lining postcapillary venules and microcirculation express on their membranes leukocyte-specific adhesion molecules both constitutively and in response to a wide range of inflammatory mediators such as IL-1 and TNF- $\alpha$ (14-16). In particular, the vascular selectin, endothelial-leukocyte adhesion molecule 1 (ELAM-1 $)^{1}$, is inducible by inflammatory stimuli (17-18) and facilitates the adhesion of PMN (18, 19), monocytes (20), and discrete subsets of memory $\mathrm{T}$ lymphocytes to endothelial cells $(21,22)$. This process is believed to be essential for the following steps of adhesion strengthening and transmigration of leukocytes through the vessel wall (15). Moreover, in some pathological conditions,

1. Abbreviations used in this paper: BCS, bovine calf serum; ELAM-1, endothelial-leukocyte adhesion molecule-1; FGF, fibroblast growth factor; HUVEC, human umbilical vein endothelial cells. 
such as in immunologically mediated chronic inflammation, an extensive vascular proliferation is known to occur (23). In fact, inflammatory cells infiltrating the perivascular space, including lymphocytes and macrophages, are also potent inducers of endothelial cell proliferation $(24,25)$.

In this study we have investigated the effect of IL-3 on proliferation and functional activation of human umbilical vein endothelial cells (HUVEC). We present evidence that unstimulated HUVEC express the transcript for both $\alpha$ and $\beta$ subunits of the IL-3 receptor and that they bind ${ }^{125}$ I-IL-3 with a single class of high-affinity receptors. We also demonstrate that IL-3 stimulates proliferation and functional activation of endothelial cells.

\section{Methods}

Cells. HUVEC were isolated from human umbilical cord within $4 \mathrm{~h}$ of delivery by trypsin (Difco Laboratories, Inc., Detroit, MI) treatment $(0.1 \%)$ and cultured in M199 (endotoxin tested, Sigma Chemical Co., St. Louis, MO) with the addition of $20 \%$ bovine calf serum (BCS) (endotoxin tested, Hyclone Laboratories, Inc., Logan, UT) and $10 \mathrm{ng} /$ ml human recombinant fibroblast growth factor- $\beta$ (FGF) (kindly provided by Dr. F. Bertolero, Farmitalia/Carlo Erba, Nerviano, Italy). HUVEC were characterized by morphologic criteria and positive immunofluorescence for factor VIII antigen. Contamination with blood leukocytes was assessed by immunofluorescence analysis using an anti-CD45 antibody.

HUVEC proliferation. The proliferative activity of HUVEC was assessed both by the determination of the fraction of cells in the $S$ phase and by direct cell count. These experiments were performed with cells between the second and fourth passage. Cells were detached from confluent cultures by trypsinization, washed, resuspended at $5 \times 10^{4} / \mathrm{ml}$ in M199 with the addition of 20\% BCS, seeded in 24-well plates (Costar Data Packaging Co., Cambridge, MA), and allowed to adhere. After 24 $\mathrm{h}$ the medium was replaced with M199 with the addition of $15 \%$ BCS, and the cells were incubated for different periods of time with $25 \mathrm{ng} / \mathrm{ml}$ IL-3 (human recombinant [hr] IL-3, a gift from Sandoz, Basel, Switzerland) or $10 \mathrm{ng} / \mathrm{ml}$ FGF. Thereafter the medium and the growth factors were replaced every other day. To evaluate the proportion of cells in DNA synthesis the cultures were pulse-labeled for the last hour of incubation with [ ${ }^{3} \mathrm{H}$ ] thymidine $(4 \mu \mathrm{Ci} / \mathrm{ml}$ ) (New England Nuclear, Boston, MA; $6.7 \mathrm{Ci} / \mathrm{mM}$ ). Cytospin preparations of trypsin-detached cells were then processed for autoradiography by standard methods. Cell proliferation was evaluated by direct cell count on trypan bluenegative cells with a hemocytometer.

Binding assay. Endothelial cells used for IL-3 binding studies were on their third passage with no contaminant $\mathrm{CD} 45^{+}$cells. HUVEC from subconfluent cultures were detached by treatment with 1 mM EDTA in PBS and gentle shaking, washed twice with cold PBS, and resuspended at the concentration of $1 \times 10^{7}$ in $100 \mu l$ of the binding buffer (RPMI 1640 containing 10\% BCS, 2 g/liter $\mathrm{NaHCO}_{3}, 50 \mathrm{mg} /$ liter gentamicin, $4 \times 10^{-5} \mathrm{M} 2$ - $\beta$-mercaptoethanol, $10 \mathrm{mM}$ Hepes buffer, pH 7, and $0.2 \%$ sodium azide). Increasing amounts of ${ }^{125} \mathrm{I}$-hrIL-3 (Amersham International, Amersham, UK; sp act $560 \mathrm{Ci} / \mathrm{mmol}$ ) were dissolved in $100 \mu \mathrm{l}$ of binding buffer and added to the cells. Nonspecific binding was evaluated by adding 100-fold molar excess of cold IL-3 to the radiolabeled cytokine before mixing with the cell suspension. After $90 \mathrm{~min}$ of incubation at $37^{\circ} \mathrm{C}$, the cells were washed twice, resuspended in $300 \mu \mathrm{l}$ of binding buffer, layered over $300 \mu \mathrm{l}$ of BCS in polyethylene microfuge tubes, and centrifuged at $10,000 \mathrm{~g}$ for $5 \mathrm{~min}$ at room temperature. The supernatant was aspirated and cell pellets were sliced off for determination of radioactivity. The radioactivity bound in the presence of excess of cold ligand was subtracted from the total binding to yield the specific binding. Nonspecific binding accounted for $5-10 \%$ of the total radioactivity bound. All samples were tested in duplicate and the range of values of each set of duplicate determinations was always $\leq 10 \%$ of the mean value. IL-3 data analysis and curve fitting were performed using the computerized LIGAND programs, Version 3.0 (Elsevier-BIOSOFT, Cambridge, UK).

Northern blot analysis. Total cellular RNA was isolated from HUVEC by using guanidinium thiocyanate and isolated by acid phenolchloroform extraction (26). Cycloheximide treatment $(20 \mu \mathrm{g} / \mathrm{ml})$ was performed for $2 \mathrm{~h}$. Northern blot analysis was performed according to standard methods as described (27). Filters were hybridized to ${ }^{32} \mathrm{P}$ random-priming labeled DNA probes (27), washed for $30 \mathrm{~min}$ in 0.1 $\times$ standard saline-citrate $/ 1 \%$ SDS at $52^{\circ} \mathrm{C}$, and exposed to $\mathrm{X}$-ray film for 2-4 d. The following probes were used: human IL-3 receptor $\alpha(6)$ and $\beta(5)$ subunits cDNA, ELAM- 1 cDNA (18), $\beta$-actin cDNA.

Isolation and labeling human neutrophils and purified $C D 4^{+} T$ cells. Neutrophils were isolated from venous blood of normal donors by gelatin sedimentation ( $2.5 \%$ gelatin in PBS, pH 7.2, for $30 \mathrm{~min}$ at $37^{\circ} \mathrm{C}$ ) and Ficoll-Hypaque gradient. $\mathrm{CD}^{+} \mathrm{T}$ cells were obtained from the mononuclear nonadherent cell fraction, by E-rosetting at $29^{\circ} \mathrm{C}$ for $2 \mathrm{~h}$ and further purified by negative selection with anti-CD8 monoclonal antibody and complement-mediated lysis. The isolated PMN (95$100 \% \mathrm{PMN}$ ) and the $\mathrm{CD}^{+} \mathrm{CD}^{+}$lymphocytes were suspended in M199 with $10 \%$ BCS for ${ }^{111}$ In-labeling and for studies of adherence to HUVEC as described by Zimmerman et al. (28). For labeling with ${ }^{111}$ In (Amersham International; sp act $12 \mathrm{mCi} / \mu \mathrm{g}$ ) $\sim 20 \times 10^{6} \mathrm{PMN}$ and $50 \times 10^{6} \mathrm{CD}^{+}$cells were suspended in $3 \mathrm{ml}$ of M199 and added with ${ }^{111}$ In at the final concentration of $1 \mu \mathrm{Ci} / \mathrm{ml}$ and further processed as described (28).

Adherence studies. Endothelial monolayers that had been tightly confluent for a minimum of $24 \mathrm{~h}$ were washed with endotoxin-free medium and incubated for $8 \mathrm{~h}$ at $37^{\circ} \mathrm{C}$ in an atmosphere of $5 \% \mathrm{CO}_{2}$ with either IL-1 $\beta$, IL-3, or IL-3 preincubated for $30 \mathrm{~min}$ with a neutralizing concentration of anti-IL-3 antiserum (kindly provided by Dr. S. C. Clark, Genetics Institute, Cambridge, MA). Aliquots of $500 \mu \mathrm{l}$ of labeled cell suspensions were then layered over the HUVEC and incubated at $37^{\circ} \mathrm{C}$ for $20 \mathrm{~min}$. The cell suspensions were then carefully aspirated from the monolayers, the monolayers were washed once with medium, and the washings were added to the supernatants and counted. The remaining endothelial cells were lysed in 10\% Triton for 5 min, scraped, and counted individually. The percent adherence was calculated by the formula: cpm (lysed cells)/cpm ( supernatant) $+\mathrm{cpm}$ (lysed cells).

\section{Results}

Cell proliferation. The effects of IL-3 on HUVEC proliferation were studied by culturing the cells in the presence of $25 \mathrm{ng} / \mathrm{ml}$ of IL-3. Dose-response experiments (data not shown) demonstrated that in our system this concentration yielded maximal response. FGF, used as the reference growth factor, was added at the concentration of $10 \mathrm{ng} / \mathrm{ml}$. As shown in Table I, IL-3treated cultures showed an increase of cells in the $S$ phase of about two- and threefold above controls on days 2 and 4, respectively. To confirm that IL-3-induced DNA synthesis was related to cell proliferation, triplicate cultures of HUVEC in 24well plates were incubated with IL-3 or FGF for up to $8 \mathrm{~d}$ and actual HUVEC numbers were determined every $2 \mathrm{~d}$. As shown in Table I, in the absence of growth factor, no significant increase in the cell number was detected. IL-3 was able to support cell proliferation up to day 6 with a maximal fivefold increase of the seeded cell number. By day 8 , in spite of medium replacement, the number of cells fell. In contrast, FGF-treated cells did not stop proliferating, reaching confluence on day 8 .

Expression of $I L-3$ receptors on HUVEC cells. In Fig. 1 Scatchard plot analysis of ${ }^{125}$ I-IL-3 specific binding on HUVEC is illustrated. The data yield a straight line indicative of a single class of binding sites. The number of receptors expressed per cell was $99 \pm 12$ with a calculated apparent $K_{\mathrm{d}}$ of $149 \pm 30 \mathrm{pM}$.

$I L-3 R \quad m R N A$ expression. The presence of IL-3 receptors 
Table I. Effects of IL-3 and FGF- $\beta$ on HUVEC DNA Synthesis and Proliferation

\begin{tabular}{clccc}
\hline $\begin{array}{c}\text { Days of } \\
\text { culture }\end{array}$ & & Controls & IL-3 & FGF \\
\hline 2 & Percentage of cells in the S-phase & 6.8 & 13.2 & 16.7 \\
& Number of cells* & 6.3 & 8.5 & 8.7 \\
4 & Percentage of cells in the S-phase & 5.8 & 21.5 & 41.5 \\
& Number of cells & 5.1 & 11 & 13.3 \\
\multirow{2}{*}{6} & Number of cells & 4.4 & 24.3 & 41 \\
8 & Number of cels & 3.5 & 21.4 & confluent
\end{tabular}

* Number of cells per well per $10^{-4}$. Cells were resuspended at $5 \times 10^{4}$ $\mathrm{ml}$ in M199 with the addition of $20 \%$ BCS, seeded in 24-well plates, and allowed to adhere. After $24 \mathrm{~h}$ the medium was replaced with M199 with the addition of $15 \%$ BCS and the cells were incubated for different times with or without IL-3 $(25 \mathrm{ng} / \mathrm{ml})$ or FGF- $\beta(10 \mathrm{ng} / \mathrm{ml})$. For the determination of the proportion of cells in the $S$ phase, triplicate cultures were pulse-labeled with $\left[{ }^{3} \mathrm{H}\right] \mathrm{TdR}(4 \mu \mathrm{Ci} / \mathrm{ml})$ for $1 \mathrm{~h}$ on the second and fourth day after the addition of the growth factors and processed for autoradiography. Cell proliferation was assessed at the indicated times by direct cell count on triplicate wells. The results represent the means of three individual experiments.

on HUVEC was further investigated by Northern blot analysis. Data shown in Fig. 2 demonstrate that the transcripts of the $a$ and $\beta$ subunits of the IL- 3 receptor are expressed in HUVEC. The accumulation of the specific transcripts observed in cycloheximide-pretreated cells indicate an efficient translation of the $\alpha$ and $\beta$ subunit mRNAs. The same transcripts were detected in the M-07e cell line (4) used as positive control and were absent in the bladder carcinoma 5637 cell line used as

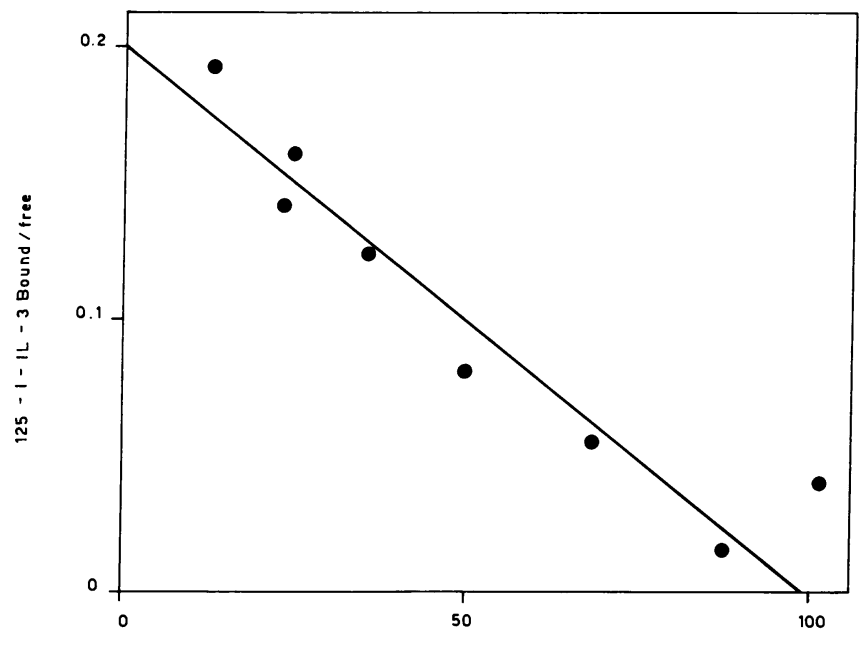

$125-I-I L-3$ Bound ( molecules /cell)

Figure 1. Scatchard plot analysis of ${ }^{125}$ I-IL-3-specific binding to subconfluent endothelial cells. The cells were detached by treatment with $1 \mathrm{mM}$ EDTA in PBS, washed, and resuspended at the concentration of $1 \times 10^{7}$. Increasing amounts of ${ }^{125}$ I-IL-3 were added to the cells. Nonspecific binding was evaluated by adding 100 -fold molar excess of cold IL-3 to the radiolabeled cytokine. The radioactivity bound in the presence of excess of cold ligand was subtracted from the total binding to yield the specific binding. All sample were tested in duplicate and data reported are the mean of three individual experiments.
A

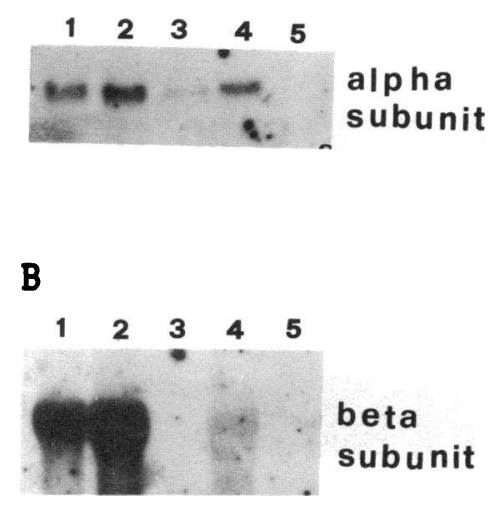

Figure 2. Expression of IL-3 receptor $\alpha$ and $\beta$ subunit mRNAs. Northern blot analysis of total RNA ( $20 \mu \mathrm{g} /$ lane) from untreated (lane 1 ) and cycloheximide-treated $(20$ $\mu \mathrm{g} / \mathrm{ml}$ per $2 \mathrm{~h}$ ) (lane 2 ) $\mathrm{M}-07 \mathrm{e}$ cells used as positive control, from untreated (lane 3 ) and cycloheximide-treated (lane 4) subconfluent HUVEC, and from 5637 cells (lane 5) used as negative control. The same filter was hybridized with specific cDNA probes for the $\alpha(A)$ and the $\beta(B)$ subunits of the IL-3 receptor.

negative control. The finding that both genes encoding for the two subunits of the IL-3 receptor are expressed in HUVEC is in agreement with the presence of IL-3 high-affinity binding sites.

Transcriptional activation of ELAM-1. Stimulation of human endothelial cells in vitro with TNF, IL-1, or bacterial lipopolysaccharide induces an activated state $(14,16)$. This activation includes the transient expression of ELAM-1 whose transcript is first seen $1 \mathrm{~h}$ after agonist incubation and it is maximal at $4 \mathrm{~h}(18)$. The results shown in Fig. $3 A$ demonstrate that IL-3 and IL-1 $\beta$-treated HUVEC exhibit similar kinetics of ELAM1 gene expression. Moreover, as shown in Fig. $3 B$, the specificity of the IL-3 effect was confirmed by the ability of a rabbit anti-human IL-3 antibody to inhibit ELAM-1 induction. Dose-response analysis shown in Fig. 4 demonstrates that the maximal effect of IL-3 on ELAM-1 gene expression is achieved at the concentration of $15-30 \mathrm{ng} / \mathrm{ml}$.

Adherence of neutrophils and $C D 4^{+} T$ cells to HUVEC. Cytokine activation of endothelial cells increases the adherence of peripheral blood leukocytes. Data reported in Table II demonstrate that IL-3 is almost equally effective as IL-1 (73\% vs. $81 \%$ ) in stimulating neutrophils adhesion. In contrast, IL-3 is more effective than IL-1 on CD4 ${ }^{+}$cell adhesion ( $55 \%$ vs. $39 \%$ ). Moreover, the results demonstrated that anti-IL-3 antiserum almost completely prevents IL-3-induced cell adhesion.

\section{Discussion}

Vascular endothelium responds to various stimuli, not simply as a target for injury, but by undergoing specific alterations in function, metabolism, and structure that may directly influence the evolution and outcome of the response to injury (13, 14). A large number of studies have shown that inflammatory cells and the factors they produce are potent inducers of $\mathrm{HU}$ VEC proliferation and activation $(14,24,25,29)$. Activated T lymphocytes and macrophages represent the major source of such factors (11). Among the pathological processes in which endothelial cells are locally related to activated $\mathrm{T}$ lymphocytes are the immunologically mediated chronic inflammations, such as rheumatoid arthritis and other autoimmune diseases. Moreover, activated T lymphocytes, which massively infiltrate inflamed tissue, e.g., allergen-injected sites, express the transcripts of several lymphokines, including IL-3 (12). These observations led us to investigate a possible role of this factor on proliferation and functional activation of endothelial cells. 

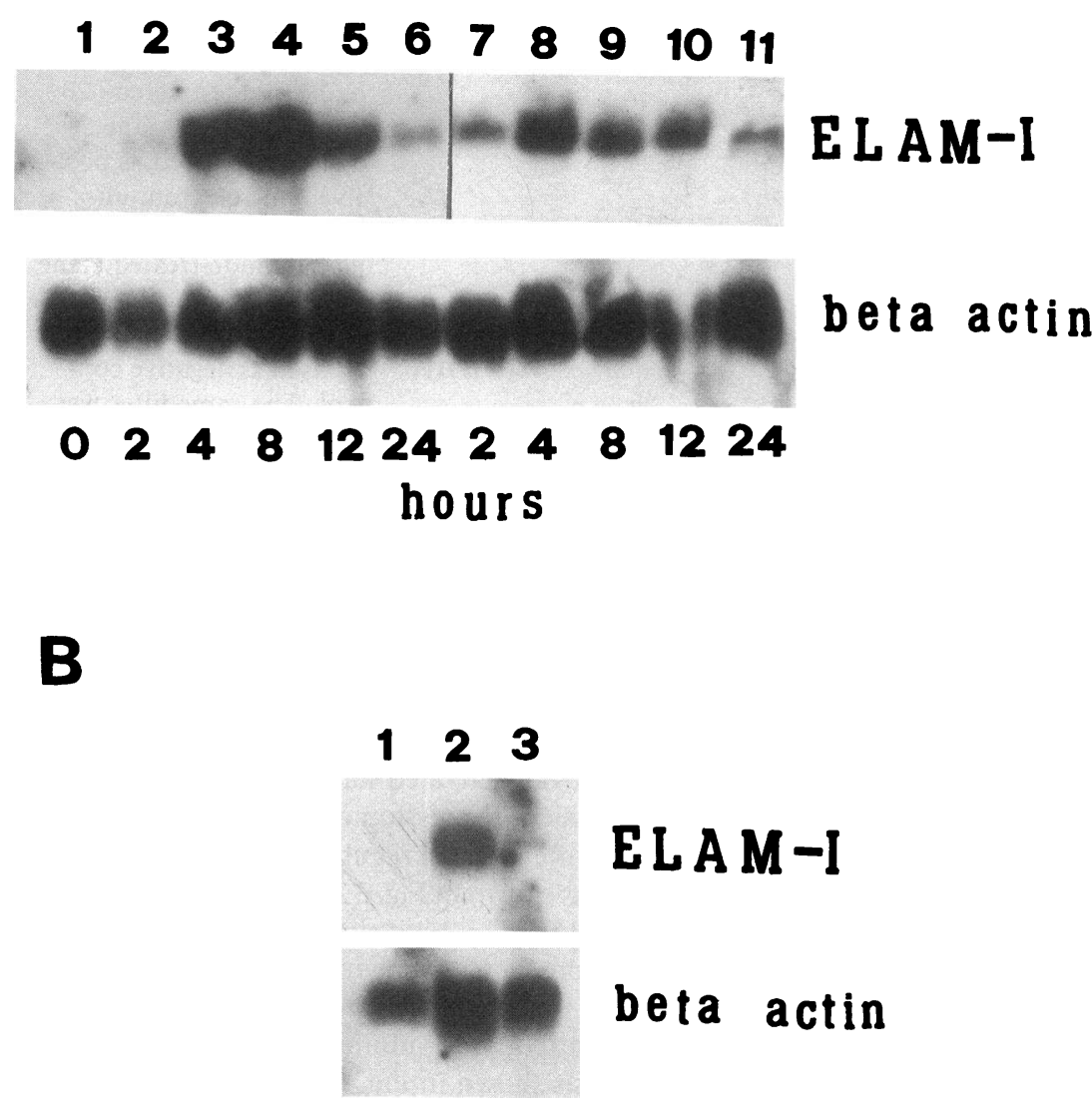

Figure 3. $(A)$ Kinetics of ELAM-1 gene activation by IL- $1 \beta$ and IL-3. HUVEC monolayers were incubated in medium alone (lane 1 ) or medium containing IL-1 (hrIL-1 $\beta$, Genzyme Corp., Cambridge, MA; $10 \mathrm{U} / \mathrm{ml}$ ) (lanes 2-6), or IL-3 $(20 \mathrm{ng} / \mathrm{ml})$ (lanes $7-11)$ for the times indicated. Total cellular RNA ( $20 \mu \mathrm{g} /$ lane) was isolated and Northern blot was prepared as described. To verify equal RNA loading among lanes the filter was rehybridized with $\beta$-actin-specific cDNA probe. $(B)$ Inhibition of IL-3-induced ELAM-1 gene activation by anti-IL-3 antiserum. HUVEC were incubated for $4 \mathrm{~h}$ in medium alone (lane 1 ), in medium additioned with $20 \mathrm{ng} / \mathrm{ml} \mathrm{IL-3}$ (lane 2), or in medium additioned with $20 \mathrm{ng} /$ $\mathrm{ml} \mathrm{IL-3}$ preincubated for $30 \mathrm{~min}$ with neutralizing concentration of anti-IL-3 antiserum (lane 3).
The increase of the proportion of cells in the $S$ phase and of the cell number seen by our experiments clearly demonstrates that IL-3 stimulates both DNA synthesis and cell proliferation and shows that IL-3 not only recruits HUVEC in the cycle but also drives them through cell division. Moreover, the finding that IL-3-sustained proliferation declines after a few days, even with continuous replacement of medium and growth factor, suggests, as recently reported (30), that a self-limiting growth mechanism could also be operating. The recent report on the

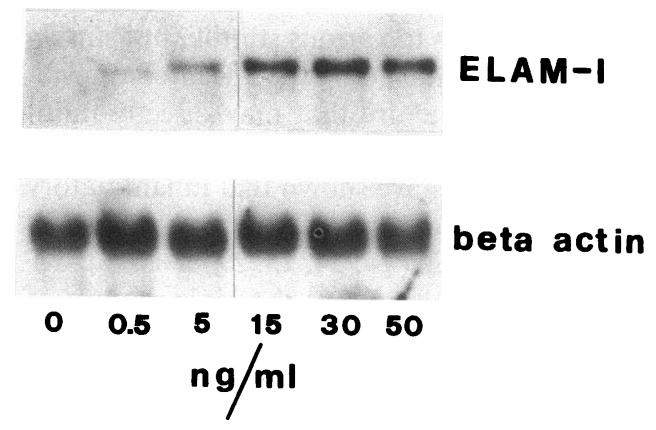

Figure 4. IL-3 dose-dependent ELAM-1 gene activation. HUVEC monolayers were incubated for $4 \mathrm{~h}$ in medium alone (lane 1 ) or medium containing the indicated concentrations of IL-3 (lanes 2-6). Total cellular RNA ( $20 \mu \mathrm{g} /$ lane) was isolated and Northern blot was prepared as described. To verify equal RNA loading among lanes the filter was rehybridized with $\beta$-actin specific cDNA probe. increase of endothelial cell number observed in patients treated with IL-3 (31) suggests that the effect of IL-3 on HUVEC proliferation may also be operative in vivo.

We have also shown that this effect is mediated by a small number of high-affinity receptors. This finding is in agreement with the observation that normal blood cells, such as monocytes (32) and eosinophils (3), and IL-3-dependent cells (4)

Table II. Effect of IL-3 on Neutrophils and $\mathrm{CD4}^{+}$Cells Adherence to HUVEC

\begin{tabular}{lcc}
\hline \multirow{2}{*}{ Agonists } & \multicolumn{2}{c}{ Percentage of adherent cells } \\
\cline { 2 - 3 } & Neutrophils & CD4 $^{+}$cells \\
\hline Buffer & $22.6 \pm 6.5$ & $19.3 \pm 3$ \\
IL-1 $\beta$ & $41 \pm 7$ & $27 \pm 4$ \\
IL-3 & $39.3 \pm 7.3$ & $30 \pm 4.6$ \\
IL-3 + anti-IL-3 & $25 \pm 6$ & $21 \pm 2$ \\
\hline
\end{tabular}

Tightly confluent endothelial cells in 24-well tissue culture plates were stimulated for $8 \mathrm{~h}$ with either IL-1 $\beta(10 \mathrm{U} / \mathrm{ml}), \mathrm{IL}-3(20 \mathrm{ng} / \mathrm{ml})$, or IL-3 $(20 \mathrm{ng} / \mathrm{ml})$ preincubated for 30 min with neutralizing amount of anti-IL-3 antiserum. ${ }^{111}$ In-labeled neutrophils $\left(2.5 \times 10^{6}\right)$ or CD4 ${ }^{+}$ cells $\left(7.5 \times 10^{6}\right)$ were resuspended in $0.5 \mathrm{ml}$ of M199, layered over endothelial cells in individual wells, and incubated for $20 \mathrm{~min}$ at $37^{\circ} \mathrm{C}$. The percentage of adherent cells was calculated as described. Data reported represent the mean of seven separate experiments each performed in duplicate. 
express a limited number of high-affinity IL-3 receptors. The human high-affinity IL-3 receptor is composed of an IL-3-specific $\alpha$ subunit, which specifically binds IL-3 (6), and by a $\beta$ subunit, which is shared with the receptor for GM-CSF (6) and the receptor for IL-5 (7). We tested the ability of these cytokines to compete with IL-3 binding sites. The results (not shown) demonstrated that the IL-3 binds specifically to its receptor, and that neither GM-CSF nor IL-5 competes with IL-3 for the binding to its receptor. We also present evidence that HUVEC express the transcripts for both the $\alpha$ and $\beta$ subunits of the IL-3 receptor. The mRNAs of the two subunits are clearly detectable only when the cells are treated with cycloheximide, an inhibitor of mRNA translation. This observation suggests that HUVEC efficiently transcribe and translate the IL-3 receptor genes.

The recruitment of leukocytes from the blood is one of the most dramatic cellular responses to tissue damage and inflammation, and is central to the physiologic trafficking of lymphocytes. Leukocyte extravasation is exquisitely regulated in vivo by mechanisms of selective mutual leukocyte-endothelial cell recognition (14). The inflammatory cytokines IL-1 and TNF, and bacterial endotoxins act directly on cultured human endothelium to increase the adhesion of blood leukocytes $(17,18)$. This event occurs through an activation of endothelium including the transient expression of endothelial cell surface molecules that promote leukocyte adherence. These adhesion molecules include intracellular adhesion molecule $1(33,34)$, ELAM-1 (18), and vascular cell adhesion molecule $1(35,36)$. In particular, neutrophyls first bind ELAM-1 expressed on the membrane of endothelial cells activated by IL-1 or TNF (14, $17,18)$. Similarly, in the chronic inflammation of the skin, the binding of $\mathrm{T}$ lymphocytes to cytokine-stimulated endothelial cells involves the expression of ELAM-1 (21). However, this initial interaction may be insufficient to overcome intravascular shear force completely; a second step involving adhesion strengthening ensures a complete stop of leukocytes followed by transmigration through the venular wall (15). Thus, through this two-step process, the sites of recalcitrant inflammation can cause a chronic immigration and accumulation of antigen-specific lymphocytes and monocytes. These cells, activated in response to inflammatory cytokines, may release IL-3 among other inflammatory mediators (12).

The results of this study provide the first evidence that IL-3, like IL-1 and TNF, activates ELAM-1 gene transcription and stimulates neutrophils and $\mathrm{CD} 4^{+} \mathrm{T}$ cell adhesion to HUVEC, suggesting a regulatory role of this lymphokine in the leukocyte-endothelial cell recognition. It can be speculated that the effects of IL-3 on endothelium may be indirect, in that it may be mediated by IL-1 produced by endothelium itself. However, the finding that IL-1 inhibits $(29,30)$, whereas IL-3 stimulates endothelial cell proliferation, and that ELAM-1 gene expression after IL-3 stimulation displays the same kinetics of that induced by IL-1 (18), argues against this supposition.

Proliferation and functional activation of endothelial cells in vivo and in vitro can be elicited by a vast array of lymphocyte- or monocyte-derived factors. Some of these factors, like GM-CSF and G-CSF $(37,38)$, have been reported to induce proliferation and migration of endothelial cells, whereas others, like IL-1 and TNF, induce endothelial cells to express adhesion molecules and to negatively modulate their proliferation $(18,29,30)$. The present study demonstrates that IL-3 stimulates not only HUVEC proliferation but also ELAM-1 gene activation and neutrophil and $\mathrm{CD}^{+}{ }^{+}$cell adhesion. These findings suggest that locally released IL-3 may support the coexistence of neovascularization and leukocyte recruitment within the sites of chronic inflammation.

\section{Acknowledgments}

The authors are grateful to Dr. G. Camussi for his helpful comments and to Dr. G. Cacace for his help in leukocyte labeling.

This work was supported by Associazione Italiana Ricerca sul Cancro (AIRC) by Consiglio Nazionale delle Ricerche, Progetto Finalizzato A.C.R.O., and by ISS IV Progetto AIDS. M.F. Brizzi is a fellow of AIRC; P. R. Rossi is a fellow of G. Ghirotti Foundation. We thank Dr. T. Kitamura, DNAX, Palo Alto, CA, for IL-3 receptor $\alpha$ and $\beta$ subunit cDNA probes and Dr. M. Introna, Istituto Farmacologico Mario Negri, Milano, for ELAM-1 cDNA probe.

\section{References}

1. Clark, S. C., and R. Kamen. 1987. The human hemopoietic growth factors. Science (Wash. DC). 236:1229-1237.

2. Park, L. S., D. Friend, V. Price, D. Anderson, J. Singer, K. S. Prickett, and D. L. Urdal. 1989. Heterogeneity of human interleukin-3 receptor. J. Biol. Chem. 264:5420-5427.

3. Lopez, A. F., J. M. Eglinton, D. Gillis, L. S. Park, S. C. Clark, and M. A. Vadas. 1989. Reciprocal inhibition of binding between interleukin-3 and granulocyte-macrophage colony-stimulating factor to human eosinophils. Proc. Natl. Acad. Sci. USA. 86:7022-7026.

4. Brizzi, M. F., G. C. Avanzi, F. Veglia, S. C. Clark, and L. Pegoraro. 1990. Expression and modulation of IL-3 and GM-CSF receptors in human growth factor-dependent leukaemic cells. Br. J. Haematol. 76:201-209.

5. Hayashida, K., T. Kitamura, D. M. Gorman, K. Arai, T. Yokota, and A. Miyajima. 1990. Molecular cloning of a second subunit of the receptor for human granulocyte-macrophage colony-stimulating factor (GM-CSF): reconstitution of a high-affinity GM-CSF receptor. Proc. Natl. Acad. Sci. USA. 87:9655-9659.

6. Kitamura, T., N. Sato, K. Arai, and A. Miyajima. 1991. Expression cloning of the human IL-3 receptor cDNA reveals a shared beta subunit for the human IL-3 and GM-CSF receptors. Cell. 66:1165-1174.

7. Tavernier, J., R. Devos, S. Cornelis, T. Tuypens, J. Van der Heyden, W. Fiers, and G. Plaetinck. 1991. A human high affinity interleukin-5 receptor (IL5R) is composed of an IL5-specific alpha chain and a beta chain shared with the receptor for GM-CSF. Cell. 66:1175-1184.

8. Wimperis, J. Z., C. M. Niemeyer, C. A. Sieff, B. Mathey-Prerot, D. G. Nathan, and R. J. Arceci. 1989. Granulocyte-macrophage colony-stimufating factor and interleukin-3 mRNA are produced by a small fraction of blood mononuclear cells. Blood. 74:1525-1530.

9. Wodnar-Filipowicz, A., C. H. Heusser, and C. Moroni. 1989. Production of the hemopoietic growth factors GM-CSF and IL-3 by mast cell in response to IgE receptor-mediated activation. Nature (Lond.). 339:150-152.

10. Razin, E., K. Leslie, and J. W. Schrader. 1991. Connective tissue mast cells in contact with fibroblasts express IL-3 mRNA. Analysis of singles cells by polymerase chain reaction. J. Immunol. 146:981-987.

11. Dinarello, C. A., and J. W. Mier. 1987. Lymphokines. N. Engl. J. Med. 317:940-945.

12. Kay, A. B., S. Ying, V. Varney, M. Gaga, R. S. Durham, R. Moqbel, A. J. Wardlaw, and Q. Hamid. 1991. Messenger RNA expression of the cytokine gene cluster, interleukin 3 (IL-3), IL-4, IL-5, and Granulocyte-Macrophage Colonystimulating factor, in allergen-induced late-phase cutaneous reactions in atopic subjects. J. Exp. Med. 173:775-778.

13. Pober, J. S., and R. S. Cotran. 1990. The role of endothelial cells in inflammation. Transplantation. 50:537-544.

14. Osborn, L. 1990. Leukocyte adhesion to endothelium in inflammation. Cell. 62:3-6.

15. Butcher, E. C. 1991. Leukocyte-endothelial cell recognition: three or more steps to specifity and diversity. Cell. 67:1033-1036.

16. Harlan, J. M. 1985. Leukocyte-endothelial interaction. Blood. 65:513525.

17. Bevilacqua, M. P., J. S. Pober, D. L. Mendrick, R. S. Cotran, and M. A Gimbrone, Jr. 1987. Identification of an inducible endothelial-leukocyte adhesion molecule, E-LAM-1. Proc. Natl. Acad. Sci. USA. 84:9238-9242.

18. Bevilacqua, M. P., S. Stengelin, J. M. A. Gimbrone, and B. Seed. 1989. Endothelial leukocyte adhesion molecule 1: an inducible receptor for neutrophils related to complement regulatory proteins and lectins. Science (Wash. DC). 243:1160-1165. 
19. Debrina, A., B. R. Schwartz, T. M. Carlos, H. D. Ochs, P. G. Beatty, and J. M. Harlan. 1989. CD11/CD18-independent neutrophil adherence to inducible endothelial-leukocyte adhesion molecules (E-LAM) in vitro. Immunology. 67:502-508.

20. Carlos, T., N. Kovach, B. Schwartz, M. Rosa, B. Newman, E. Wayner, C Benjamin, L. Osborn, R. Lobb, and J. Harlan. 1991. Human monocytes bind to cytokine-induced adhesive ligands on cultured human endothelial cells: endothelial-leukocyte adhesion molecule-1 and vascular cell adhesion molecule-1. Blood. 77:2266-2271.

21. Picker, L., T. K. Kishimoto, C. W. Smith, R. A. Warnock, and E. C. Butcher. 1991. ELAM-1 is an adhesion molecule for skin-homing T cells. Nature (Lond.). 349:796-799.

22. Shimizu, Y., S. Shaw, N. Graber, T. V. Gopal, K. J. Horgan, G. A. Van Seventer, and W. Newman. 1991. Activation-independent binding of human memory T cells to adhesion molecule ELAM-1. Nature (Lond.). 349:799-802.

23. Malone, D. G., S. M. Wahl, M. Tsokoo, H. Catel, J. L. Decker, and R. L. Wilder. 1984. Immune function in severe, active rheumatoid arthritis. J. Clin. Invest. 74:1173-1185.

24. Polverini, P., R. S. Cotran, M. A. Jr. Gimbrone, and E. R. Unanue. 1977. Activated macrophages induce vascular proliferation. Nature (Lond.). 269:804806 .

25. Watt, S. L., and R. Auerbach. 1986. A mitogenic factor for endothelia cells obtained from mouse secondary mixed leukocytes cultures. J. Immunol. 136:197-207.

26. Chomczynski, P., and N. Sacchi. 1987. Single step method of RNA isola tion by acid guanidinium thiocyanate-phenol-chloroform extraction. Anal. Biochem. 162:156-161.

27. Sambrook, J., E. F. Fritsch, and T. Maniatis. 1989. Molecular Cloning. Cold Spring Harbor Laboratory, Cold Spring Harbor, NY.

28. Zimmerman, G. A., T. M. McIntyre, and S. M. Prescott. 1985. Trombin stimulates the adherence of neutrophils to human endothelial cells in vitro. $J$ Clin. Invest. 76:2235-2246.

29. Saegusa, Y., M. Ziff, L. Welkovich, and D. Cavender. 1990. Effect of inflammatory cytokines on human endothelial cell proliferation. J. Cell. Physiol. 142:488-495.
30. Cozzolino, F., M. Torcia, D. Aldinucci, M. Ziche, F. Almerigogna, D. Bani, and D. M. Stern. 1990. Interleukin 1 is an autocrine regulator of human endothelial cell growth. Proc. Natl. Acad. Sci. USA. 87:6487-6491.

31. Orazi, A., G. Cattoretti, R. Sciró, S. Siena, M. Bregni, M. Di Nicola, and A. M. Gianni. 1992. Recombinant human interleukin 3 and recombinant human granulocyte-macrophage colony-stimulating factor administrated in vivo after high dose cyclophosphamide cancer chemotherapy: effect on hematopoiesis and microenvironment in human bone marrow. Blood. 79:2610-2619.

32. Budel, L. M., O. Elbaz, H. Hoogerbrugge, R. Delwel, L. A. Mahmoud, B. Lowenberg, and I. P. Touw. 1990. Common binding structure for GranulocyteMacrophage colony-stimulating factor and Interleukin 3 in human acute myeloid leukemia cells and monocytes. Blood. 75:1439-1445.

33. Simmons, D., M. W. Makgoba, and B. Seed. 1988. ICAM, an adhesion ligand of LFA-1, is homologous to the neural cell adhesion molecule NCAM. Nature (Lond.). 331:624-627.

34. Stauton, D. E., S. D. Marlin, C. Stratowa, M. L. Dustin, and T. A. Springer. 1988. Primary structure of ICAM-1 demonstrates interaction between members of the immunoglobulin and integrin supergene families. Cell. 52:925933.

35. Osborn, L., C. Hession, R. Tizard, C. Vassallo, S. Luhowskyj, G. ChiRosso, and R. Lobb. 1989. Direct expression cloning of vascular cell adhesion molecule 1, a cytokine-induced endothelial protein that binds to lymphocytes. Cell. 59:1203-1211.

36. Carlos, T. M., B. R. Schwartz, N. L. Kovach, E. Yee, M. Rosa, L. Osborn, G. Chi-Rosso, B. Newman, R. Lobb, and J. M. Harlan. 1990. Vascular cell adhesion molecule-1 mediates lymphocyte adherence to cytokine-activated cultured human endothelial cells. Blood. 76:965-972.

37. Bussolino F., J. M. Wang, P. Defilippi, F. Turrini, F. Sanavio, C. J. Edgell, M. Aglietta, P. Arese, and A. Mantovani. 1988. Granulocyte- and granulocytemacrophage colony-stimulating factor induce human endothelial cells to migrate and proliferate. Nature (Lond.). 337:471-473.

38. Bussolino, F., M. Ziche, J. Ming Wang, D. Alessi, L. Morbidelli, O. Cremona, A. Bosia, P. C. Marchisio, and A. Mantovani. 1991. In vitro and in vivo activation of endothelial cells by colony-stimulating factors. J. Clin. Invest. 87:986-995 